\title{
Knowledge and Attitude towards Obesity among Secondary School Students of Royal Crystal College, Ile-Ife, Nigeria
}

\author{
Article by Arilewola Abosede Omotola \\ Ph.D in Public Health, Texila American University, Nigeria \\ E-mail: tolabanjo24@yahoo.com
}

\begin{abstract}
Background: Obesity has reached an epidemic proportion in the developing and developed countries. It contributes or serves as risk factors to many non-communicable diseases. Knowledge and attitude of adolescent needs be assessed as childhood obesity has been found to translate to obesity in adulthood.

Methods: This study is a cross-sectional study to investigate knowledge about obesity risk factors and attitudes of students of secondary school, Ile-Ife, Osun State, Nigeria.

A pretested 34 item, purpose designed and structured, self-administered questionnaire were used to collect information on knowledge and attitudes of the respondent on knowledge and attitudes towards obesity. Data were collated and analyzed based on descriptive and inferential study design.

Results: The result showed that the total percentages of respondents with good level of knowledge is $58.2 \%$ (232), and $42.2 \%$ (168) respondents having poor knowledge level. About $24.1 \%$ of the respondents had favorable attitude to obesity, $531.9 \%$ had moderate favorable attitude and 22\% had unfavorable attitude toward obesity. In addition, the result showed no significant association between demographic variables and knowledge scores and significant association between attitude scores and class and type of housing composition of secondary school students $(p<0.05)$. The results also showed significant correlation between knowledge score and attitude score of the students $(p<0.05)$.

Conclusion: It was, therefore, concluded that the secondary school students of Royal Crystal College, Ile-Ife have good knowledge and favorable attitude towards obesity.
\end{abstract}

Keywords: Obesity, knowledge, attitude.

\section{Introduction}

Obesity has reached an epidemic proportion in the developing and developed countries (Bocquier et al 2005). The prevalence is increasing in the world generally. The major cause is said to be an imbalance between the calories intake and calories output and other factors of importance are dietary change, inactivity and genetic predisposition (Ekpenyong et al, 2011, Obirikorang et al 2016). Obesity is defined as excessive or abnormal accumulation of fat in the body that predisposes risk to health (Njelekela et al, 2015; Ranjit Kaur 2014, Shrivastava et al 2013). Obesity is defined as a body mass index of $30 \mathrm{~kg} / \mathrm{m} 2$ or more ( $\mathrm{K}$. Duval et al, 2006). Obesity is a leading cause of death in the recent time and present as a cause of life threatening diseases. (Tagbo et al, 2015, Chukwuonye et al, 2013; Ekpenyong et al, 2011).

Adolescent are the age group that falls between 10-19 years. There has being an increase in childhood obesity over the past two decades. It is estimated that childhood obesity may likely persist through adulthood. It is said to increase the risks of non-communicable disease in later life. About 43 million children were estimated globally as overweight and obese in the year 2010, majorities were from developing countries. (Njelekela et al, 2015). Childhood obesity is on the alarming increase in the world in terms of prevalence (Mwaikambo et al, 2015). Obesity is understood as a growing health problem in Africa (Pangani et al, 2016)

Public health internationally gives priority to the prevention of childhood obesity because of its significance on acute and chronic diseases, development and on general health (Waters et al, 2011). 
Knowledge is a major powerful toll in prevention. Knowledge as a weapon is needed in the prevention of a disorder as obesity. Adolescents get involved in attitudes and habits that can predispose them to being overweight or obese sometimes due to lack of knowledge about it causes and how to prevent it (Adeleke et al 2015). The best effective way of dealing with overweight and obesity is aimed at helping the masses have knowledge and understand it adverse effect/dangers and have attitudes that prevent the condition. Also a good attitude towards obese people and obesity can help prevent the rise in tide of obesity. This study aimed at assessing the knowledge about obesity and its risks and attitudes of secondary school student in Ile-Ife Nigeria.

There are many studies on obesity prevalence, knowledge in adult and young females (under graduates). Likewise, knowledge and attitudes of mothers. There are limited research findings to determine knowledge and attitudes of adolescent that is secondary school student in Nigeria. However; this study is, therefore directed to investigate the knowledge and attitude of secondary school students of royal crystal college, Ile-Ife Nigeria as a case sample.

\section{Significance of study}

There is need to assess the knowledge and attitude of adolescent because they are more likely to engage in unhealthy eating habits, do less activity and exercises in this industrialized age and are very susceptible to obesity in this age group which can span through adulthood and create health challenges both now and in the future. Also assessing their basic knowledge and attitude is essential for developing and educative and preventive programs. Lastly, the results and findings from this study can help to put certain policies in place in-terms of individual and community policies.

\section{Statement of problem}

Many studies have shown prevalence of obesity is on the increase almost from childhood to adolescent and adult stage. Many have worked on the knowledge of adult especially on obesity adult's adverse effect. Since obesity is observed to be on the increase in adolescent which spread to adulthood. To the best of my knowledge, limited studies focused on adolescent has been found in the literature and there is no formal study conducted on knowledge and attitude of secondary school student in Ile-Ife, Nigeria.

Therefore this study aimed at assessing the knowledge and attitude of adolescent to obesity.

\section{Research questions}

The major research questions for this study include the followings.

- What is the knowledge based level of Royal Crystal College student about obesity

- What are the attitudes of Royal Crystal College student to obesity

\section{Research objectives}

1. To assess knowledge level of adolescents on obesity.

2. To assess attitude level of adolescents to obesity

3. To correlate knowledge score and attitude score of adolescent to obesity

4. To find out association between knowledge score and some demographic variables

5. To find out association between attitude score and some demographic variable

\section{Literature review}

Children obesity is seen as a potential health problem in Nigeria due to the changes in lifestyle patterns. This is associated with a major medical, psychological and health consequence for children and adolescents. (Adegoke et al, 2009). Obesity is a noncommunicable multi -factorial metabolic disorder characterized by accumulation of white adipose tissue (WAT) in subcutaneous intra-abdominal and vascular organs in vertebrates (Daniel et al, 2016). Obesity has become an epidemic afflicting all nations over the world. The obesity epidemic affects all age groups including very young children and is a serious 
and growing problem for public health systems worldwide. The rapid rise in the prevalence of obesity is accompanied by the increasing number of co morbidities. (Mazur et al, 2013). Obesity among children and adolescents is rising far more than two decades, appears to have hit a plateau, a potentially significant milestone in the battle against excessive weight gain among children and adolescent. In Brazil, the progression of the nutritional transition has been detected. It has been characterized by the reduction of the prevalence of nutritional deficits and the more expressive occurrence of overweight and obesity, not only in the adult population, but also among children and adolescents. Triches and Giugliani 2005)

The World Health Organization classifies about 400 million people around the world as obese. About $15 \%$ of adolescents (aged12-19years) and children aged (6-11years) are obese in the United State and numbers are expected to continue to increase. In the United Kingdom in 2004 , it was estimated that $14 \%$ of boys and $17 \%$ of girls in the age group of $2-15$ years were obese. Childhood obesity represents one of the worlds' greatest health challenges. (Ismail et al, 2011). Obesity increases the risk for serious health conditions that affect their present, future health and quality of life, including resistance type 2 diabetes, metabolic syndrome, high blood pressure, abnormal blood lipid level and low self-esteem, Stroke, certain cancers (Cardozo et al, 2013) heart and kidney failure (Adebayo et al, 2014; Awotidebe et al, 2014;Ogunmola et al, 2013). Obesity is socially and culturally acceptable in Nigeria and therefore, not usually recognized as a medical condition. (Iloh et al, 2010). Obesity is a major health problem, and there is an increasing trend of overweight and obese individual in developing countries (Bocquier et al, 2005). Being overweight or obese is known to contribute significantly to morbidity and mortality rates in various countries around the world.

There are several classifications and definitions of obesity; however, the commonly adopted is the definition by the World Health Organization (WHO) which defines obesity as a body mass index (BMI) of $30 \mathrm{~kg} / \mathrm{m} 2$ or more. Obesity is associated with major and minor diseases (Chukwuonye et al, 2013). Ogunbode et al, (2014) cited obesity as a noncommunicable disease which is gaining increasing importance globally and is rapidly emerging disease in the developed world. It is chronic a condition characterized by an accumulation of body fat. It is one of the most important preventable diseases in developed countries. The prevalence of the disease is increasing in both industrialized nations and in those undergoing alterations in diet and activity patterns as a consequence of adoption of the western culture.

The origin of obesity is unclear but it appears to be multi factorial and requires the continuous differentiation of new adipocyte throughout life. This process of adipocyte differentiation firm preadipocytes has been shown to be controlled by members of the peroxisome prolife rator-activated receptor (PPARv). There is said to be genetic basis for the development of obesity. There may be other factors influencing the expression of genetic character tics that induce weight gain or allow weight loss. It leptin is a protein or hormone that is produced by adipocytes it regulates body weight metabolism and reproductive function. In obesity, there is excessive adipose tissue mass. Obesity results when the body's intake is greater than output over a period of time due to a sedentary lifestyle. This dietary factors and physical activity patterns play a strong role in obesity and this is called exogenous obesity. Obesity is positively associated with dietary factors such as increased fat intake, low fiber consumption, increased hidden sugars in prepared foods, reduce amounts of unrefined sugars, and inadequate fruit and vegetable intake. The daily eating pattern also see $\mathrm{ms}$ to be associated with weight change, especially chrome diet, which can be measured in several ways.

A physical activity pattern such as sedentary lifestyle is associated with weight change. The physical activity pattern has important influence on physiological regulation of body weight. Decrease physical activity plays an important influence on physiological regulation of body weight. Other lifestyle factors which could cause obesity include insufficient sleep, endocrine disruptors food substance which interface with lipid metabolism, decreased 
variability in ambient temperature and decrease rates of smoking which suppress appertite (Ogunbode et al, 2011) psychological factors, endocrine problems, other social determinants to obesity include the income differential, marital status, and BMI change friends, sibling or spouse irrespective of geographical distance. Childhood and adolescent obesity has also been identified as risk factors for obesity in adulthood (Ogunbode et al, 2011).

In classifying obesity, it earn be classified as central or peripheral obesity. In central obesity, otherwise called 'android' obesity, the distribution of fat is commonly on the upper part of the trunk (chest and abdomen) and is more common in the males. Android obesity is more clearly associated lipid and with disordered lipid and glucose metabolism and diseases like diabetes mellitus gout, atherosclerosis, osteoarthritis, cardiovascular disease especially hypertension, and some cancers. In the peripheral or "gynecoid" type of obesity, the distribution of fat is mainly on the hip and thighs and is more common in females (Ogunbode et al, 2011)

There are various measures of obesity and the BMI is a very useful and common one. It is calculated as weight in kilograms divided by the square of the heights in meters. The BMI takes into account both frame and size and body composition and considered to provide a realistically achievable range of healthy weights and is a predictor of danger associated with obesity. Normal BMI is between $18.5-24.9 \mathrm{~kg} / \mathrm{m}^{2}$, BMI greater or equal to $25 \mathrm{~kg} / \mathrm{m} 2$ is overweight, obesity is BMI of $30 \mathrm{kgm}^{2}$ or more. There are 3 grades of obesity. Grades one is between $30-34.9 \mathrm{~kg} / \mathrm{m} 2$ grade 2 (moderate) is between BMI $35-39.9 \mathrm{~kg} / \mathrm{m} 2$ and grade 3 , extreme or morbid obesity is BMI of $40 \mathrm{~kg} / \mathrm{m} 2$ and more.

Waist hip ratio (WHR) is another means of knowing if a person is obese and is calculated by using the ratio of waist circumference to hip circumference. WHR is classified as 0.70 0.80 as normal, 0.81- 0.86 as moderate and 0.86 as severe obesity. (Ogunbode et al, 2011; Ranjit Kaur et al, 2014)

Prevention of obesity should involve primary and secondary prevention with emphasizes. The healthcare cost of obesity are considerable, especially when complicated by diabetes mellitus, osteoarthritis, hypertension, gallstone disease, post menopausal breast cancer and colon cancer. Prevention of obesity is thus cost effective and should begin in early childhood by instilling and healthy patterns of exercises and diet.

Given that there is a much higher risk of overweight adolescents becoming overweight adults, engaging young people in physical activity remain a key behavioral target for obesity prevention. Specific treatment for obesity will be determined by the adolescent's age, overall health, and medical history, extent of the condition, adolescents' tolerance for specific medications, procedures or therapies, opinion or preference. Treatment for obesity in adolescents may include the following nutritional and individual diet counseling. Modification or diet and caloric content, increased exercise participation in an appropriate exercise program behavior modification, individual or group therapy focused on changing behaviors and confronting feelings related to weight and normal developmental issues.

Ranjit Kaur et al 2014. The increasing body or literature supporting that childhood obesity persist throughout adult life make it very imperative to study and understand factors associated with childhood obesity including knowledge and attitudes of adolescents towards obesity.

\section{Methods}

\section{Research design, study area and population}

A descriptive cross sectional study was conducted on personal knowledge and attitude of secondary school student of Royal Crystal College, Ile-Ife, Osun State, Nigeria. The study was carried out in royal crystal college, a very well-known private secondary school in Ile-Ife town. Ile-Ife is an ancient city of Yoruba land situated in Osun state which is located in the south-western part of Nigeria. The study population consisted of the secondary school students boys and girls both in the junior and senior secondary school one, two and three (JSS1- JSS3,SSS1-SSS3) of the college. 


\section{Data collection}

Information was collected from respondent by means of a pretested 34 item designed, selfadministered anonymous questionnaire containing open and close ended questions.

The questionnaire was divided into four major sections. Section 1 containing, 11 items focused on demographic characteristics of respondents. Section 2 containing 4 items focus on definition and source of information about obesity. Section 3: consist of 10 items related to Adolescent knowledge on risk factors in obesity it's a structured knowledge questionnaire designed for adolescents. The items are multiple choice questions with 3 alternative responses. A score of 1 is allotted to a correct response, score of 0 for wrong and don't know answers. The total score for knowledge is 10 .

Section 4: Consisted of 9 items that assesses attitudes. It is a structured attitude scale. AORK was modified from ORK 10. Swift et al, 2006

\section{Ethical consideration}

Permission to conduct this study was sought, obtained and granted by the school authority. Likewise, informed consent was also obtained from the students

\section{Sample size determination}

The minimum sample size was calculated using the Leslie and kish formular for descriptive studies.

$\mathrm{N}=\mathrm{P}(\mathrm{I}-\mathrm{P}) \mathrm{z} 2 / \mathrm{D} 2$, where $\mathrm{N}$ is the minimum sample size needed; $\mathrm{D}$ is the level of error $\mathrm{D} 2$ that can be tolerated ( 0.05 chance of error) and $\mathrm{P}$, the estimated proportion of level of knowledge among primary school student from previous study (Njelekela et al 2015) was $45 \%$ i.e $\mathrm{P}=0.45$. $\mathrm{Z}$ is the standard variation corresponding to confidence level. At confidence level of $95 \% \mathrm{Z}=1.96$. Therefore $\mathrm{N}=0.45(1-0.45) 1.962 / 0.052=380$. To give allowance for an anticipated non response rate of $10 \%$ (about 40 respondents), the sample size was increase by 40 to make 420 respondents. Out of the 420,400 respondent supplied adequate information to an extent, others having unfilled spaces.

\section{Sampling method}

A sample of 400 student from royal crystal college Ile-Ife (48\% males and 52\% females) were involved in the study. The age ranged from 10-21years, respondent were provided with an assurance of confidentiality of information provided in the questionnaire.

\section{Data analysis}

The completed questionnaires were collated analyzed and presented using descriptive statistics of simple percentages, frequency distribution, mean and range where applicable. Inferential statistics of chi-square was used to determine the association between Sociodemographic variable and knowledge and attitude. Pearson product moment correlation coefficient was used to determine the correlation between knowledge and attitude of secondary school students of Royal Crystal College, Ile Ife to obesity. Data was analyzed with SPSS 17

\section{Results}

\section{Demographic characteristics of the study population}

A total number of 400 secondary school students of Royal Crystal College, Ile Ife participated in the study in which $(48 \%)$ of them were males and $(52 \%)$ were female. Majority of the respondents (47\%) were between the ages of 13 and 15 years. The result also showed that the highest percentage of students were from JSS 3 class distribution (20.8\%). Highest percentages of them were Christians $(83.5 \%)$ as reflected by the result. The results also showed that largest percentages of them were Yoruba (88.3\%), majority of the mothers were into business $(41.3 \%)$ and highest fathers' occupation was farming (31.0\%). Mothers' highest level of education was at secondary school (36.3\%) and that of fathers was at the level 
Texila International Journal of Public Health

Volume 5, Issue 1, Mar 2017

of college (47.8\%). Monogamy ranked the highest under type of family (71.8\%) and about $(39.5 \%)$ lives in duplex as shown in Table1.

Table 1. Demographic Characteristics of the study population

\begin{tabular}{|c|c|c|c|}
\hline Serial numbers & variables & $\begin{array}{l}\text { Frequency } \\
\text { (F) }\end{array}$ & $\begin{array}{l}\text { Percentage } \\
(\%)\end{array}$ \\
\hline 1 & $\begin{array}{l}\text { Age in years } \\
10-12 \\
13-15 \\
16-18 \\
19-21\end{array}$ & $\begin{array}{l}135 \\
188 \\
70 \\
7\end{array}$ & $\begin{array}{l}33.8 \\
47.0 \\
17.5 \\
1.8\end{array}$ \\
\hline 2 & $\begin{array}{l}\text { Sex } \\
\text { Male } \\
\text { Female } \\
\end{array}$ & $\begin{array}{l}192 \\
208\end{array}$ & $\begin{array}{l}48.0 \\
52.0\end{array}$ \\
\hline 3 & $\begin{array}{l}\text { Class } \\
\text { JSS 1 } \\
\text { JSS2 } \\
\text { JSS3 } \\
\text { SSS1 } \\
\text { SSS2 } \\
\text { SSS3 }\end{array}$ & $\begin{array}{l}77 \\
34 \\
83 \\
77 \\
74 \\
55\end{array}$ & $\begin{array}{l}19.3 \\
8.5 \\
20.8 \\
19.3 \\
18.5 \\
13.8\end{array}$ \\
\hline 4 & $\begin{array}{l}\text { Religion } \\
\text { Christianity } \\
\text { Islam } \\
\text { Traditional } \\
\text { Nil response }\end{array}$ & $\begin{array}{l}334 \\
56 \\
7 \\
3\end{array}$ & $\begin{array}{l}83.5 \\
14.0 \\
1.8 \\
.8\end{array}$ \\
\hline 5 & $\begin{array}{l}\text { Tribe } \\
\text { Yoruba } \\
\text { Igbo } \\
\text { Hausa } \\
\text { Others } \\
\text { Nil response }\end{array}$ & $\begin{array}{l}353 \\
28 \\
4 \\
14 \\
1\end{array}$ & $\begin{array}{l}88.3 \\
7.0 \\
1.0 \\
3.5 \\
.3 \\
\end{array}$ \\
\hline 6 & $\begin{array}{l}\text { Mother } \\
\text { occupation } \\
\text { Housewife } \\
\text { Business } \\
\text { Farmer } \\
\text { Government } \\
\text { Employee } \\
\text { Self employee } \\
\text { Nil response }\end{array}$ & $\begin{array}{l}56 \\
165 \\
32 \\
97 \\
\\
45 \\
5\end{array}$ & $\begin{array}{l}14.0 \\
41.3 \\
8.0 \\
24.3 \\
\\
11.3 \\
1.3\end{array}$ \\
\hline 7 & $\begin{array}{l}\text { Father } \\
\text { occupation } \\
\text { Business } \\
\text { Farmer } \\
\text { Government } \\
\text { Employee } \\
\text { Self employed }\end{array}$ & $\begin{array}{l}116 \\
124 \\
119 \\
41 \\
\end{array}$ & $\begin{array}{l}29.0 \\
31.0 \\
29.8 \\
\\
10.3\end{array}$ \\
\hline 8 & $\begin{array}{l}\text { Mother } \\
\text { education level } \\
\text { No Formal } \\
\text { Primary } \\
\text { Secondary }\end{array}$ & $\begin{array}{l}22 \\
56 \\
145 \\
\end{array}$ & $\begin{array}{l}5.5 \\
14.0 \\
36.3 \\
\end{array}$ \\
\hline
\end{tabular}




\begin{tabular}{|c|c|c|c|}
\hline & $\begin{array}{l}\text { College } \\
\text { University } \\
\text { Nil response }\end{array}$ & $\begin{array}{l}134 \\
40 \\
3\end{array}$ & $\begin{array}{l}33.5 \\
10.0 \\
.8\end{array}$ \\
\hline 9 & $\begin{array}{l}\text { Father } \\
\text { education level } \\
\text { No Formal } \\
\text { Primary } \\
\text { Secondary } \\
\text { College } \\
\text { University } \\
\text { Nil response } \\
\end{array}$ & $\begin{array}{l}15 \\
33 \\
102 \\
191 \\
49 \\
10\end{array}$ & $\begin{array}{l}3.8 \\
8.3 \\
25.5 \\
47.8 \\
12.3 \\
2.5\end{array}$ \\
\hline 10 & $\begin{array}{l}\text { Type of family } \\
\text { Single Parent } \\
\text { Parents } \\
\text { Divorced } \\
\text { Monogamy } \\
\text { Polygamy } \\
\text { Nil response } \\
\end{array}$ & $\begin{array}{l}37 \\
31 \\
287 \\
37 \\
8 \\
\end{array}$ & $\begin{array}{l}9.3 \\
7.8 \\
71.8 \\
9.3 \\
2.0\end{array}$ \\
\hline 11 & $\begin{array}{l}\text { Type of } \\
\text { housing } \\
\text { Single room } \\
\text { Room and } \\
\text { Parlour } \\
2 \text { bedroom } \\
3 \text { bedroom } \\
\text { Duplex } \\
\text { others } \\
\text { Nil response }\end{array}$ & $\begin{array}{l}24 \\
49 \\
\\
83 \\
12 \\
166 \\
69 \\
5\end{array}$ & $\begin{array}{l}6.0 \\
12.3 \\
\\
20.8 \\
3.0 \\
39.5 \\
17.3 \\
1.3\end{array}$ \\
\hline
\end{tabular}

\section{Source of information and knowledge about obesity}

About $74.3 \%$ of the respondents have heard about obesity. Majority of the students about $(63 \%)$ agreed that obesity is the result of long term energy imbalances in which daily energy intake exceeds daily energy expenditure. Also (66.5\%) agreed that obesity is having too much body fat. Major source of information about obesity was through the school teacher (38.8\%), followed by that of radio $(14.5 \%)$, then from books/newspapers $(11.5 \%)$, relative and neighbor $(5.5 \%)$, health facility (10.5\%), television (8.5\%), friend at school (7.8\%), other sources $(0.5 \%)$ while there was $2.5 \%$ nil response as shown in table 2 .

Table 2. Knowledge about obesity

\begin{tabular}{|l|l|l|l|}
\hline $\begin{array}{l}\text { Serial } \\
\text { number }\end{array}$ & variables & $\begin{array}{l}\text { Frequency } \\
\text { (f) }\end{array}$ & Percentage (\%) \\
\hline 1 & Have heard of & & \\
& obesity & 297 & 74.3 \\
& $\begin{array}{l}\text { Yes } \\
\text { no }\end{array}$ & 103 & 25.7 \\
\hline 2 & Correct definition & & \\
& of obesity 1 & & \\
& Yes & 252 & 63.0 \\
& No & 40 & 10.0 \\
& Don't know & 101 & 25.3 \\
& Nil response & 7 & 1.8 \\
\hline 3 & $\begin{array}{l}\text { Correct definition } \\
\text { of obesity 2 }\end{array}$ & & \\
\hline
\end{tabular}


Texila International Journal of Public Health

Volume 5, Issue 1, Mar 2017

\begin{tabular}{|l|l|l|l|}
\multicolumn{1}{|c|}{} & Yes & 266 & 66.5 \\
& No & 57 & 14.3 \\
Don't know & 74 & 18.5 \\
& Nil response & 3 & 0.8 \\
\hline 4 & Source of & & \\
information about & & \\
obesity & & \\
School Teacher & 155 & 38.8 \\
& Radio & 58 & 14.5 \\
Books/newspaper & 46 & 11.5 \\
& Friend at school & 22 & 5.5 \\
Relative/neighbour & 42 & 10.5 \\
& Health facility & 34 & 8.5 \\
Television & 31 & 7.8 \\
& Other sources & 2 & 0.5 \\
& Nil response & 10 & 2.5 \\
\hline
\end{tabular}

\section{Knowledge score of adolescent obesity risk knowledge scale (AORK)}

To determine the level of knowledge, scoring for each question is assessed for correctness and the total score obtained is between $0-10$. The total percentages of respondents with poor level of knowledge risk, scoring between $0-4$ of the total score is $42 \%$ (168), scores between 5-10 with 58\%. (232) respondents have good level of knowledge of obesity (as in Table 3a). The mean of the obesity risk knowledge score of the respondents was calculated to be $4.65 \pm$ 2.22.Table $3 \mathrm{~b}$ shows the total number and the percentages of correct responses given by the secondary school students of Royal Crystal College on the whole questionnaire on obesity risk knowledge. More than half of the respondents (63.5\%) knew a person who has diabetes can sometimes get better by losing weight, item 1 . Respondents also scored high in items 2, 5, $6,8,9$, with $55.5 \%, 57.0 \%, 53.0 \%, 55.3 \%$ and $56.0 \%$ respectively. $84.0 \%$ were of the opinion that it is less of a health problem when a person has fat around the stomach and waist than someone who has fat around the hips and thighs. Incorrect answers also reflected high percentages in items $4,7,10$, with $52 \%, 51.7 \%$ and $84.3 \%$ respectively.

Table 3a. Grading of knowledge scores of samples on obesity risks

\begin{tabular}{|l|l|l|l|}
\hline Score & grade & Frequency (f) & Percentage (\%) \\
\hline $0-4$ & Poor knowledge & 168 & 42.1 \\
\hline $5-10$ & Good knowledge & 232 & 58.2 \\
\hline Total & & 400 & 100 \\
\hline
\end{tabular}

Table 3b. Responses to adolescent obesity risk knowledge (AORK)

\begin{tabular}{|l|l|l|l|l|l|l|}
\hline $\begin{array}{l}\text { Adolescent obesity risk } \\
\text { questions and responses }\end{array}$ & $\begin{array}{l}\text { Yes } \\
(\%)\end{array}$ & $\begin{array}{l}\text { No } \\
(\%)\end{array}$ & $\begin{array}{l}\text { Don't } \\
\text { know } \\
(\%)\end{array}$ & $\begin{array}{l}\text { Nil } \\
\text { response } \\
(\%)\end{array}$ & $\begin{array}{l}\text { Percentage } \\
\text { correct }(\%)\end{array}$ & $\begin{array}{l}\text { Incorrect } \\
(\%)\end{array}$ \\
\hline $\begin{array}{l}\text { A person who has diabetes } \\
\text { can sometimes get better by } \\
\text { losing weight (true) }\end{array}$ & 63.5 & 17.0 & 18.8 & 0.8 & 63.5 & 36.6 \\
\hline $\begin{array}{l}\text { Obese people have more of a } \\
\text { chance of getting stomach } \\
\text { cancer (true) }\end{array}$ & 55.5 & 18.8 & 24.5 & 1.3 & 55.5 & 44.5 \\
\hline $\begin{array}{l}\text { It is less of a health problem } \\
\text { when a person has fat around } \\
\text { the stomach and waist than } \\
\text { someone who has fat around }\end{array}$ & 57.8 & 16.0 & 24.3 & 2.0 & 16.0 & 84.0 \\
\hline
\end{tabular}




\begin{tabular}{|l|l|l|l|l|l|l|}
\hline the hips and thighs (false) & & & & & & \\
\hline $\begin{array}{l}\text { When parents are obese, it } \\
\text { more likely that their children } \\
\text { will become obese (true) }\end{array}$ & 47.5 & 39.8 & 12.0 & 0.8 & 47.5 & 52.0 \\
\hline $\begin{array}{l}\text { On average, obese people do } \\
\text { not live as long as people with } \\
\text { normal weight (true) }\end{array}$ & 57.0 & 24.8 & 16.8 & 1.5 & 57.0 & 43.0 \\
\hline $\begin{array}{l}\text { Obesity increases the risk of } \\
\text { getting breast cancer in } \\
\text { women (true) }\end{array}$ & 53.0 & 20.5 & 26.0 & 0.5 & 53.0 & 47.0 \\
\hline $\begin{array}{l}\text { "being obese" and "being fat" } \\
\text { mean different things (true) }\end{array}$ & 48.3 & 31.8 & 17.8 & 2.3 & 48.3 & 51.7 \\
\hline $\begin{array}{l}\text { Taking a bottle of soft drink } \\
\text { every day is something that } \\
\text { can contribute to a person } \\
\text { obese (true) }\end{array}$ & 55.3 & 21.3 & 16.8 & 6.8 & 55.3 & 44.7 \\
\hline $\begin{array}{l}\text { Obesity can often cause } \\
\text { problem with your heart (true) }\end{array}$ & 56.0 & 20.5 & 22.0 & 1.5 & 56.0 & 44 \\
\hline $\begin{array}{l}\text { Being fat when you are in the } \\
\text { middle school is less of a } \\
\text { problem because it is easy for } \\
\text { teenagers to lose weight } \\
\text { (false) }\end{array}$ & 61.8 & 15.8 & 20.5 & 2.0 & 15.8 & 84.3 \\
\hline
\end{tabular}

\section{Attitude score of adolescent to obesity}

In the attitude of the respondents to obesity, 22\% (88) had unfavorable attitude towards obesity with a score between $0-3,53.9 \%$ (215) had moderate favorable attitude with scores between 4-6 and 24,1\% (97) had favorable attitude with scores between 7-9. This reflected in table $4 \mathrm{a}$. The mean score for attitude was $4.78+-2.13$ as the standard deviation. Table $4 \mathrm{~b}$ shows the attitude response of the participants. Almost two third (63.8\%) of the respondents disagree with the statement that it is good to look obese and about $77.0 \%$ agrees that adolescent should do physical activity. Majority (73.0\%) agreed that eating unhealthy food is risky to children

Table 4a. Grading of attitude scores of adolescents to obesity

\begin{tabular}{|l|l|l|l|}
\hline Score & grade & $\begin{array}{l}\text { Frequency } \\
\text { (f) }\end{array}$ & Percentage (\%) \\
\hline $0-3$ & Unfavourable attitude & 88 & 22.0 \\
\hline $4-6$ & Moderate favourable & 215 & 53.9 \\
\hline $7-9$ & favourable & 97 & 24.1 \\
\hline
\end{tabular}

Table 4b. Participant responses to attitude questions

\begin{tabular}{|l|l|l|l|l|l|l|l|}
\hline $\begin{array}{l}\mathrm{s} / \\
\mathrm{n}\end{array}$ & Item & $\begin{array}{l}\text { Agree } \\
(\%)\end{array}$ & $\begin{array}{l}\text { Disagr } \\
\text { ee }(\%)\end{array}$ & $\begin{array}{l}\text { Don't } \\
\text { know } \\
(\%)\end{array}$ & $\begin{array}{l}\text { Nil } \\
\text { resp } \\
\text { ons } \\
\mathrm{e} \\
(\%)\end{array}$ & $\begin{array}{l}\text { Percent } \\
\text { age } \\
\text { Correct } \\
(\%)\end{array}$ & $\begin{array}{l}\text { Percent } \\
\text { age } \\
\text { incorrec } \\
\mathrm{t}(\%)\end{array}$ \\
\hline 1 & It is good to look obese & 24.0 & 63.8 & 11.8 & 0.5 & 63.8 & 36.2 \\
\hline 2 & $\begin{array}{l}\text { It is good for adolescent to } \\
\text { do physical activity }\end{array}$ & 77.0 & 11.0 & 11.3 & 0.8 & 77.0 & 23.0 \\
\hline 3 & $\begin{array}{l}\text { Adolescents should not do } \\
\text { any physical work }\end{array}$ & 20.3 & 61.8 & 15.5 & 2.5 & 61.8 & 38.2 \\
\hline 4 & Being obese is not a & 36.0 & 44.5 & 17.5 & 2.0 & 44.5 & 55.5 \\
\hline
\end{tabular}


Texila International Journal of Public Health

Volume 5, Issue 1, Mar 2017

\begin{tabular}{|l|l|l|l|l|l|l|l|}
\hline & problem to adolescents & & & & & & \\
\hline 5 & $\begin{array}{l}\text { Eating unhealthy food is } \\
\text { risky to children }\end{array}$ & 73.0 & 15.3 & 10.3 & 1.5 & 73.0 & 27.0 \\
\hline 6 & Adolescent can be obese & 49.5 & 25.8 & 23.8 & 1.0 & 49.5 & 50.5 \\
\hline 7 & $\begin{array}{l}\text { An obese child is } \\
\text { presumed as healthy }\end{array}$ & 39.5 & 40.8 & 19.0 & 0.8 & 40.8 & 59.2 \\
\hline 8 & $\begin{array}{l}\text { Obesity is an indicator of } \\
\text { good health }\end{array}$ & 27.5 & 54.8 & 16.0 & 1.8 & 54.8 & 45.2 \\
\hline 9 & $\begin{array}{l}\text { Will be suspected with } \\
\text { HIV positive if you lose } \\
\text { weight }\end{array}$ & 41.3 & 38.0 & 18.8 & 2.0 & 41.3 & 58.7 \\
\hline
\end{tabular}

\section{Correlation between knowledge level and attitude level}

Table 5 shows the calculated correlation coefficient (r) between knowledge and attitude scores of the secondary school students considered in the study. The result showed that there was statistically moderately positive correlation between knowledge and attitude scores. $(\mathrm{r}=0.335, \mathrm{n}=400, \mathrm{p}<0.05)$. correlation is significant at the 0.01 level when $\mathrm{p}=0.000$.

Table 5. Correlations

\section{Correlations}

\begin{tabular}{|l|l|l|l|}
\hline \multirow{3}{*}{ knowscore } & & knowscore & attiscore \\
\cline { 2 - 4 } & Pearson Correlation & 1 & $.335^{* *}$ \\
\cline { 2 - 4 } & Sig. (2-tailed) & & .000 \\
\cline { 2 - 4 } & $\mathrm{N}$ & 400 & 400 \\
\hline \multirow{3}{*}{ attiscore } & Pearson Correlation & $.335^{* *}$ & 1 \\
\cline { 2 - 4 } & Sig. (2-tailed) & .000 & \\
\cline { 2 - 4 } & $\mathrm{N}$ & 400 & 400 \\
\hline \multirow{2}{*}{$* *$. Correlation is significant at the 0.01 level (2-tailed). } \\
\hline
\end{tabular}

\section{Association of knowledge scores with selected demographic variables}

Table 6 shows that were no statistically association between demographic variables and knowledge.

Table 6. association between Chi-Square result of socio demographic characteristics and knowledge among adolescents

\begin{tabular}{|l|l|l|l|l|}
\hline variables & $\begin{array}{l}\text { Chi-Square } \\
\text { value }\end{array}$ & Df & Result & P.Valve \\
\hline Age & 32.533 & 30 & NS & 0.343 \\
\hline Sex & 8.631 & 10 & NS & 0.567 \\
\hline Class & 62.829 & 50 & NS & 0.105 \\
\hline Religion & 26.539 & 30 & NS & 0.647 \\
\hline Tribe & 40.788 & 40 & NS & 0.436 \\
\hline $\begin{array}{l}\text { Occupation level of } \\
\text { mother }\end{array}$ & 64.749 & 50 & NS & 0.078 \\
\hline $\begin{array}{l}\text { Occupation level of } \\
\text { father }\end{array}$ & 27.422 & 30 & NS & 0.601 \\
\hline $\begin{array}{l}\text { Education level of } \\
\text { mother }\end{array}$ & 47.664 & 50 & NS & 0.568 \\
\hline Education level of father & 40.095 & 50 & NS & 0.841 \\
\hline Family structure & 48.872 & 40 & NS & 0.159 \\
\hline
\end{tabular}




\begin{tabular}{|l|l|l|l|l|}
\hline Type of housing & 75.689 & 60 & NS & 0.083 \\
\hline
\end{tabular}

\section{Association of attitude score with selected demographic variables}

In table 7, class and housing structure showed statistical significance, while others did not show any significant difference. It shows student class and type of housing having association with attitude

Table 7. association between Chi- Square result of socio demographic characteristics and attitude on obesity among adolescents

\begin{tabular}{|l|l|l|l|l|}
\hline variables & $\begin{array}{l}\text { Chi- } \\
\text { Square } \\
\text { value }\end{array}$ & Df & Result & P.Valve \\
\hline Age & 28.342 & 27 & NS & 0.394 \\
\hline Sex & 5.659 & 9 & NS & 0.774 \\
\hline Class & 69.790 & 45 & S & 0.010 \\
\hline Religion & 16.164 & 27 & NS & 0.950 \\
\hline Tribe & 39.957 & 36 & NS & 0.299 \\
\hline $\begin{array}{l}\text { Occupation level of } \\
\text { mother }\end{array}$ & 47.899 & 45 & NS & 0.356 \\
\hline $\begin{array}{l}\text { Occupation level of } \\
\text { father }\end{array}$ & 33.927 & 27 & NS & 0.168 \\
\hline $\begin{array}{l}\text { Education level of } \\
\text { mother }\end{array}$ & 37.489 & 45 & NS & 0.779 \\
\hline $\begin{array}{l}\text { Education level of } \\
\text { father }\end{array}$ & 50.316 & 45 & NS & 0.271 \\
\hline Family structure & 25.074 & 36 & NS & 0.961 \\
\hline Type of housing & 72.318 & 54 & S & 0.049 \\
\hline
\end{tabular}

\section{Discussion}

This study was conducted to assess the knowledge and attitude of the secondary school students of Royal Crystal College, Ile- Ife and to determine the association that exists between knowledge level and attitude level and socio-demographic characteristics of these students and also to determine if any correlation exists between their knowledge and attitude.

Obesity is a public health concern and it remains (Njelekela et al, 2015: Waters et al, 2011), a major critical issue as a precursor to non communicable diseases, such as diabetes, stroke and heart disease.(Awotidebe et al, 2014 ; Daniel et al, 2016). Obesity is on the increase in the world, the prevalence is reaching an epidemic proportion (Ranjit-Kaur, 2014). Knowledge about obesity is very important among students since adolescent obesity can develop into adulthood with its consequences (Njelekela et al, 2015). Adolescent is a vulnerable time for obesity development. (Ranjit Kaur, 2014). The sex distribution in this study had more female respondents than male respondents. This result is similar to a study carried out in 2015 which also reported female respondents higher in number than male respondents (Njelekela et al, 2015). The result also showed higher Christian respondents and Yoruba respondents than any other religions and tribes respectively. This result can be explained by the fact that the sampled private school is primarily a Christian college school located in Yoruba land. This invariably shows that the study environment will usually reflect the characteristics of the study population.

The result in this study also showed that more than half (58.2\%) of the respondents (232) have good knowledge level about obesity,42.8\% have poor knowledge (168) of the respondents on obesity. The result is contrary to the result of Rutkowski and Connelly (2015) who found out that the AORK scores were low in the two study groups they considered. Majority of the respondents had moderate to good negative attitude towards obesity, in line with Njelekela et al (2015) and Ranjit Kaur (2014). The outcome of this study also showed 
that no significant associations were found between knowledge level and demographic variables of respondents. (Ranjit- Kaur, 2014) on the contrary also her study showed that there was strong association between sex, family income, type of family, dietary habits and hobbies obesity knowledge level. The result also showed that significant association was found between attitude scores and class, and type of housing of the respondents. This implies that class and type of housing of the respondents is associated with their attitudes on the contrary to significant association found in age, sex, family income, area of residence, type of family and dietary habits in Ranjit- Kaur (2014) study. Finally, there was significant correlation between obesity knowledge score and attitudes score in line with Ranjit Kaur (2014) of the students.

\section{Limitation of the study}

One, the study is based on self- reported information and thus is subject to self- report bias. To correct this, effort was made to reduce the impact of this bias by making the questionnaire a guided self- administered process.

Two, the students involved in this study were drawn mainly from a private high school in Ile-Ife and therefore the outcome of the study cannot be generalized as they are not true representatives of all the secondary school students in Ile-Ife.

The study is limited to 400 samples.

\section{Conclusion}

The outcome of this study reveals that majority of the respondents had good knowledge about obesity risks. Likewise, majority had moderate favorable to favorable attitudes towards obesity. Also, the study shows no significant association between demographysic variables and knowledge level and significant association between attitude score with class composition of the secondary school and type of housing students. Lastly, in this study, there was significant correlation between knowledge score and attitude score on obesity of the students.

\section{Recommendation}

In view of the above conclusions, the followings are therefore recommended:

1. A study can be conducted to compare male to female knowledge and attitude levels

2. There is need to introduce obesity and its risks to children early enough in schools to reduce the alarming rates at which it is increasing among children and adolescents.

3. Knowledge about risks associated with obesity and attitude towards obesity of these private college students can be compared with those in the public or rural secondary schools.

4. Adult and adolescent knowledge level can also be considered in further research.

\section{References}

[1]. Adegoke S.A, Olowu W A, Adeodu O.O, Elusiyan J B, Dedeke I O (2009); prevalence of overweight and obesity among children in Ile-Ife, Southwestern Nigeria. West Afri j. med. July- Aug; $28(4) ; 216-21$

[2]. Adeleke S.A, Abioye-kuteyi E.A. Sikuade O.O, Olusayo A. I (2016); knowledge of obesity among the staff of the international institute of tropical agriculture, Nigeria: Int J Cur Res

[3]. Artur Mazur, Paweł Matusik, Krista Revert, Sergey Nyankovskyy, Piotr Socha, Monika Binkowska-Bury, Joanna Grzegorczyk, Margherita Caroli, Sandra Hassink, Grzegorz Telega, Ewa Malecka-Tendera (2013): Childhood Obesity: Knowledge, Attitudes, and Practices of European Pediatric Care Providers. Pediatrics, July, Volume 132 / Issue1

[4]. Aurelie Bocquier, Pierre Verger, Arnaud Basdevant, Gerard Andreotti, Jean Baretge, Patrick Villani and Alain Paraponaris (2005): Overweight and Obesity: Knowledge, Attitudes, and Practices of General Practitioners in France. Obesity research, 13:787-795. DOI: 10.1038/oby.2005.89

[5]. C.Justin David and G. kumaresan (2016): Functional genomics, MIRNAS in lipid metabolism and pharmaceutical sciences VOL3, 1ssue: 8, 513-523 
[6]. Eden R Cardozo, Tanaka J Dune, Lisa M Neff, Maureen E Brocks, Geraldine E Ekpo, Randall B Barnes and Erica E Marsh (2013):Knowledge of Obesity and Its Impact on Reproductive Health Outcomes Among Urban Women. J Community Health, April; 38(2): 261-267.

[7]. Ekpenyong, C. E, Akpan, U. P., Nyebuk E. Daniel and John O. Ibu (2011): Prevalence and assessment of overweight and obesity factors in adult population resident in uyo metropolis, Nigeria. African Journal of Bioscience, Volume 4, Number 1.

[8]. Iloh G.U, Amadi A. N, Nwankwo B.O (2010): obesity in adult Nigerians: a study of it prevalence and comment on primary co- morbidities in a semi- urban mission general hospital in south eastern Nigeria. Niger J.Med Oct-Dec, 19 (4): 459-66.

[9]. Innocent Ijezie Chukwonye, Abali Chuku, Collins John, Kenneth Arinze Ohagwu, Miracle Erinma Imoh, Samson Ejiji isa, Okechukwu Samuel Ogah and Efosa Oviasu (2013): Prevalence of overweight and obesity in adult Nigerians-a systematic review. Diabetes metab syndr obes.vol 6: 43-47.

[10]. Ismail Pangani, Festus k kiplamai, Jane w. kamau, Vincent O.Onywera (2016)' prevalence of overweight and obesity among primary school children aged 8-13 years in Dar-es salaam city, Tanzania.Adv Prev Med. Vol 2016:1345017

[11]. K. Duval, P. Marceau, L. Pérusse and Y. Lacasse (2006): An overview of obesity-specific quality of life questionnaires. Obesity reviews 7, 347-360,347. doi: 10.1111/j.1467-789X.2006.00244.x

[12]. Marina A. njelekela, Alfa muhihi, Rose N.M Mpembeni, Amani Anaeli, Omary chillo, sulende kubhoja, Benjamin Lujani, Davis Ngarashi and Mwanamkwu Magbembe (2015): knowledge and attitudes toward obesity among primary school children in Dares Salaam, Tanzania, Niger med j. marApril, 56-2);103-106.

[13]. Mosleh A. Ismail, Mohammed H. Kamel and Dalia E Ibrahim (2011): assessment of knowledge attitude and practice of adolescents towards obesity in the preparatory schools in Ismaila city Egypt. Egyptian journal community medicine.vol7, issue22, pg22-28.

[14]. Mwaikambo S. A, Leyna G.H, killewo J, Simba A and Puoane T (2015): why are primary school children overweight and obese? A cross sectional study undertaken in kinondoni district Dar-es Salaam.BMC Public Health, Dec 21; 15; 1269, doi; 10. 1186/s/ 2889-015-2596-0.

[15]. Ogunbode A.M, Ladipo M, Ajayi I. O, Fatiregun A.A (2011): Obesity an emerging disease, Niger J.Clin. Pract, 4:390-4.

[16]. Olarinde J Ogunmola; Adeleke O Olaifa, Olutoyin O Oladapo and Oluwole A Babatunde (2013): Prevalence of cardiovascular risk factors among adults without obvious cardiovascular disease in a rural community in Ekiti State, Southwest Nigeria. BMC Cardiovascular Disorders 13:89

[17]. Rasaaq A. Adebayo, Michael O Balogun, Rufus A. Adedoyin, Oluwayemisi A. Obashoro-John, Luqman A. Bisiriyu and Olugbenga O Abiodun (2014): Prevalence and pattern of overweight and obesity in three rural communities in southwest Nigeria. Diabetes, Metabolic Syndrome and Obesity: Targets and Therapy: 7 153-158

[18]. Raujit kaur, Ramesh kumari, Samuel (2014); A study to assess the knowledge and attitude of adolescents on obesity at selected senior secondary schools in Amritsar in a view to develop and distribute information booklet. IJEAR vol 4, issue 1, jan- june ISSN; 2249-4944

[19]. Rozane Márcia Triches and Elsa Regina Justo Giugliani (2005): Obesity, eating habits and nutritional knowledge among school children. Rev Saúde Pública;39(4)

[20]. Rutkowski E. M and Connelly C.D (2015): adolescent obesity risk knowledge (AORK): Let the discussion begin. Journal for specialists in pediatric nursing, 21(2016)37-43

[21]. Shrivastava S, Shrivastava P., Ramasamy J (2013): Assessment of knowledge about obesity among students in a medical college in Kancheepuram district, Tamil Nadu. Prog Health Sci, Vol 3, No1 Knowledge about obesity.pp 54-60

[22]. Tagbo Beckie N, Ndubisi Nwaezuoke, Dorothy Ihekuna, Ifeoma Mbomi, Chima Robert Ifeoma Ogbaji, Chinenye P. Tagbo (2015): Perception and attitude of Nigerian mothers toward obesity. British Journal of Medicine and medical research 5(10); 1260-1270, Article no BJMMR.2015.143.ISSN:22310614.

[23]. Taofeek Oluwole Awotidebe, Rufus Adesoji Adedoyin, Busola Fatoogun, Victor Adeyeye Chidozie Mbada, Odunayo Theresa Akinola Olubusola Esther Johnson, Nicole De Wet (2014): An 
Texila International Journal of Public Health

Volume 5, Issue 1, Mar 2017

assessment of knowledge of Nigerian female undergraduates on obesity as risk factor for cardio vascular disease in women. American Journal of Health Research 2 (5-1): 50-55

[24]. Waters E, de- Silva-Saniqorski A, Hall B. J, Brown T, Campbell k. J, Gao Y, Armstrong R, Prosser L, Summerbell C. D (2011): interventions for preventing obesity in children. Cochrane database Syst Rev Dec 7; (12); CD001871

[25]. Yaa Obirikorang, Christain Obirikorang, Enoch Odame Anto, Emmanuel Acheampong, Nyalako Dzah, Caroline Nkrumah Akosah and Emmanuella Batu Nsenbah (2016): Knowledge and LifestyleAssociated Prevalence of Obesity among Newly Diagnosed Type II Diabetes Mellitus Patients Attending Diabetic Clinic at Komfo Anokye Teaching Hospital, Kumasi, Ghana: A Hospital-Based Cross-Sectional Study. J Diabetes Res. V 2016:9759241. Doi:10.1155/2016/9759241 